KONRAD MAJ

SWPS Uniwersytet Humanistycznospoteczny

w Warszawie

\title{
UCZELNIA XXI WIEKU. SIEĆ SPOŁECZNA STUDENTÓW, ABSOLWENTÓW I KADRY NAUKOWO-DYDAKTYCZNEJ W INNOWACYJNYM MODELU KSZTAŁCENIA IDEAGORA ${ }^{1}$
}

\begin{abstract}
Maj Konrad, Uczelnia XXI wieku. Sieć społeczna studentów, absolwentów i kadry naukowodydaktycznej w innowacyjnym modelu ksztatcenia ideAGORA [The 21st Century University. Social Network of Students, Graduates and Academic Staff in an Innovative Model of Education ideAGORA]. Studia Edukacyjne nr 43, 2017, Poznań 2017, pp. 205-221. Adam Mickiewicz University Press. ISSN 1233-6688. DOI: $10.14746 /$ se.2017.43.13
\end{abstract}

This article presents the contemporary challenges faced by universities. It focuses on the traditional and the modern approach to the University maintaining relations with their socio-economic environment. These relationships are described in the framework of the social network theory. The second part presented an innovative model of education ideAGORA, the concept of lifelong learning based of a lasting relationship between university and graduate. The results of evaluations carried out after the stage of testing the ideAGORA model demonstrated its high efficiency: it contributes to strengthening alumni's ties with the University, the sincerity of their motivation to study and activity as well as the interest in additional training in the case of graduates and academic staff.

Key words: graduates, students, education, higher education, lifelong learning, social networks

1 Publikacja powstała w ramach projektu „Model kształcenia przez całe życie w oparciu o trwałą relację z uczelnią: ideAGORA - absolwenci kapitałem społecznym uczelni”, finansowanego z Europejskiego Funduszu Społecznego w ramach Programu Operacyjnego Kapitał Ludzki, działanie 4.1.1. Wzmocnienie i rozwój potencjału dydaktycznego uczelni oraz zwiększenie liczby absolwentów kierunków o kluczowym znaczeniu dla gospodarki opartej na wiedzy, poddziałanie 4.1.1. Wzmocnienie potencjału dydaktycznego uczelni. Autor artykułu był jednym z wykonawców i ekspertem w niniejszym projekcie. 


\section{Wprowadzenie}

Zarówno Komisja Europejska w ramach deklaracji bolońskiej², jak i strategia rozwoju szkolnictwa wyższego do roku $2020^{3}$ zakładają konieczność rozwoju kształcenia przez całe życie (lifelong learning) ${ }^{4}$. Jednak, jak pokazały badania PARP, 6\% absolwentów stale się dokształca, 13\% bierze udział w kursach, szkoleniach i innych formach dokształcania się, ale $81 \%$ nie dokształcało się w 2010 roku w żaden sposób, nawet przez samokształcenie. Autorzy raportu PARP podkreślają jednocześnie istotę reformy dydaktyki ukierunkowanej na ściślejsze powiązanie oferty kształcenia ustawicznego uczelni z otoczeniem społeczno-gospodarczym 5 .

Przed szkolnictwem wyższym stoją zatem pewne wyzwania, które mogą stanowić jednocześnie szansę na zmianę i rozwój w zupełnie nowych kierunkach. Obecnie uczelnie na całym świecie konkurują o studentów, a czynniki demograficzne powodują, że rywalizacja ta nasiliła się. Otwarcie się świata akademickiego na absolwentów i szeroko rozumiane otoczenie społeczne jest więc zmianą, która może uratować wiele uczelni. Ale jest w tym jeszcze inna ważna korzyść. Rynek pracy wymaga pracowników przygotowanych do wykonywania zawodu w sposób praktyczny, a pracodawcy nie mają obecnie czasu na edukowanie przygotowanych jedynie teoretycznie absolwentów. Uczelnia powiązana ze światem biznesu może stać się bardziej aplikacyjna, może mieć lepszy monitoring sytuacji na rynku pracy, a łącznikiem z tym światem mogą być absolwenci. Stanowią oni ważny kapitał społeczny, który nie powinien być marnowany. Wymaga to jednak modyfikacji dotychczasowego sposobu działania uczelni - ewolucji od struktury zamkniętej do otwartej, stale podążającej za tym co dzieje się za murami kampusu.

2 Deklaracja Bolońska, Szkolnictwo wyższe w Europie. Wspólna Deklaracja Europejskich Ministrów Edukacji, zebranych w Bolonii w dniu 19 czerwca 1999. http://ekspercibolonscy. org.pl/sites/ekspercibolonscy.org.pl/files/1999_PL_Bologna_Declaration.pdf

${ }^{3}$ Ernst\&Young, IBNGR, Strategia rozwoju szkolnictwa wyższego w Polsce do 2020 roku, 2009. https://www.nauka.gov.pl/g2/oryginal/2013_05/59579f9e6efaec82014d6d5be081ca23.pdf

${ }^{4}$ B. Matwijów, Kształcenie akademickie w perspektywie uczenia się przez całe życie (lifelong learning), [w:] W poszukiwaniu modelu dydaktyki akademickiej, red. D. Skulicz, Kraków 2004, s. 87-90.

${ }^{5}$ PARP, Studenci - przyszłe kadry polskiej gospodarki. Raport z badań studentów i analizy kierunków kształcenia realizowanych w 2010 r. w ramach projektu "Bilans Kapitału Ludzkiego" (oprac. M. Jelonek), 2011. http://bkl.parp.gov.pl/system/files/Downloads/20110616070806/Studenci__przyszle_kadry_polskiej_gospodarki.pdf?1309349876. 


\section{Relacje uczelni z otoczeniem społecznym w ujęciu tradycyjnym i nowoczesnym}

W ujęciu tradycyjnym kandydaci przychodzą na studia, tkwią na uczelni kilka lat poddawani edukacji przez kadrę naukowo-dydaktyczną, w tym czasie integrują się ze sobą, a pewnego dnia opuszczają jej mury. Kadra naukowo-dydaktyczna $\mathrm{z}$ kolei nie ma w zasadzie kontaktu $\mathrm{z}$ absolwentami oraz $\mathrm{w}$ ograniczonym stopniu ze społecznością lokalną. Uczelnia $\mathrm{w}$ tym modelu jest wyizolowaną $\mathrm{z}$ otoczenia społeczno-gospodarczego strukturą, z kolei jej absolwenci tracą wzajemny kontakt, równocześnie dochodzi do dezintegracji zbudowanej na studiach kolektywnej tożsamości (ryc. 1).

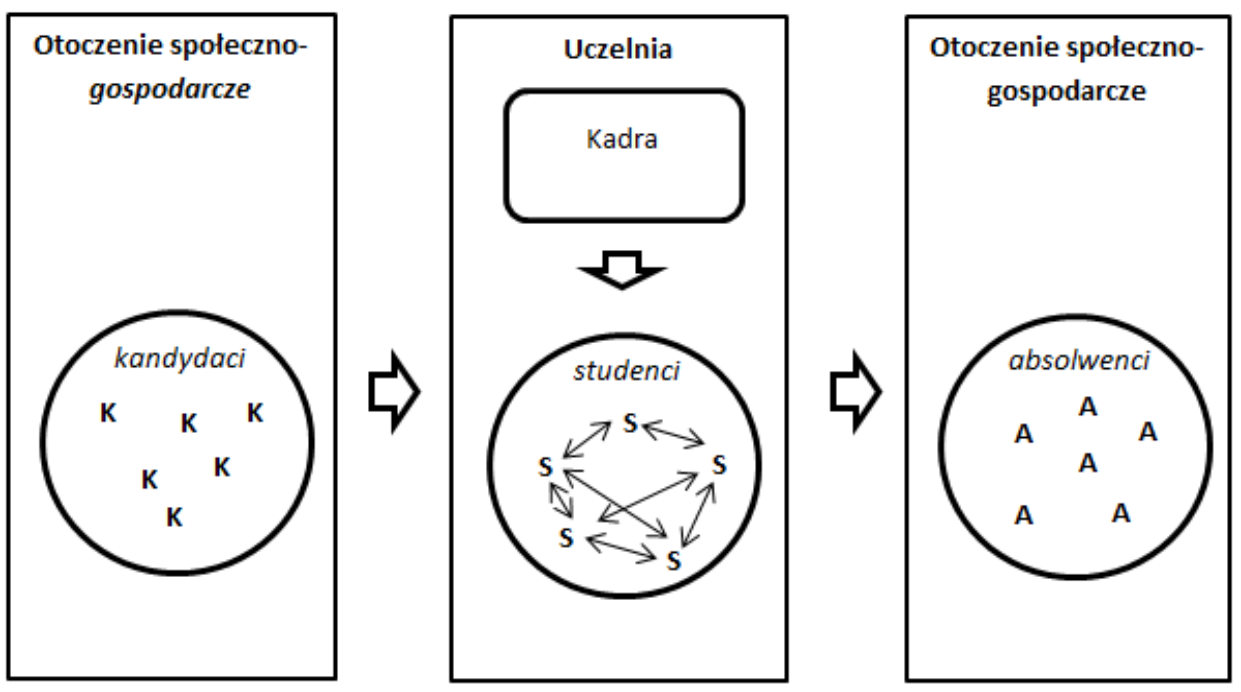

Ryc. 1. Kształcenie przez uczelnię wyższą w ujęciu tradycyjnym (opracowanie własne)

W podejściu nowoczesnym (ryc. 2) Uczelnia jest ważnym elementem otoczenia społeczno-gospodarczego, jej granice są nieostre, utrzymuje ona silne związki nie tylko ze swoimi studentami czy kandydatami, ale również z absolwentami, którzy jednocześnie są reprezentantami świata biznesu. I co najważniejsze, $\mathrm{w}$ tej półotwartej strukturze mówimy o oddziaływaniu dwukierunkowym w każdym przypadku: kadra naukowo-dydaktyczna również zmienia się pod wpływem kontaktów ze studentami, kandydatami czy absolwentami. 


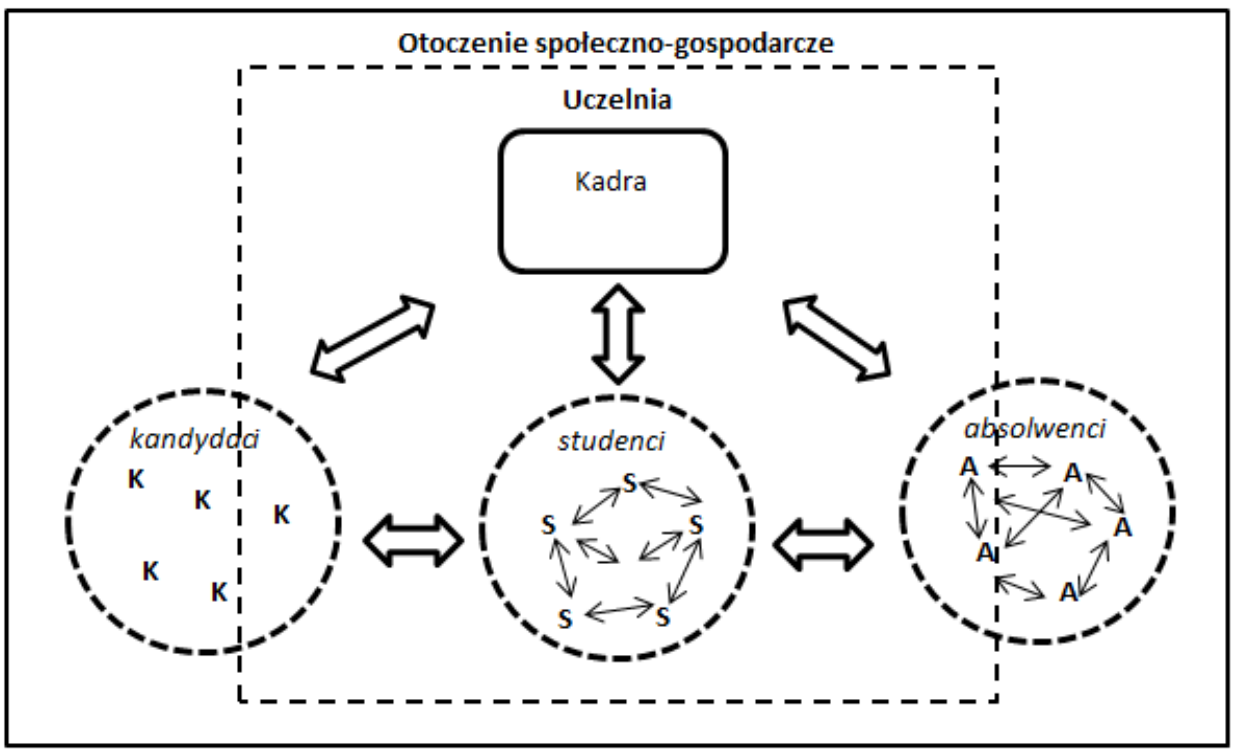

Ryc. 2. Kształcenie przez uczelnię wyższą w ujęciu nowoczesnym (opracowanie własne)

Studentem danej uczelni jest się przez pewien czas, ale później na resztę życia zostaje jej absolwentem, zatem - uczelnia nie tylko kształci studentów, ale jednocześnie przygotowuje do przyszłej roli absolwenta. Młody człowiek kończący studia zostaje swego rodzaju ambasadorem na zewnątrz, zasilając jako pracownik i działacz jej otoczenie społeczno-gospodarcze. Absolwenci mogą być szalenie użyteczni jako źródło wiedzy na temat zmian na rynku pracy, oczekiwań pracodawców, ale również pomocni w zakresie organizowania praktyk dla studentów, inspirowania i pobudzania ich do rozwoju. Absolwenci stanowią również doskonałe wsparcie edukacji studentów zarówno jako baza potencjalnych wykładowców, praktyków, ale również grupa, która w jakimś sensie może edukować i rozwijać kadrę naukowodydaktyczną.

Młody człowiek po skończeniu studiów konfrontuje nabytą wiedzę i umiejętności z wymogami stawianymi mu przez pracodawcę oraz ogólną sytuacją zawodową. Szybko orientuje się, w czym mu pomogła uczelnia, a w czym nie. Abiturient może zatem dostarczyć uczelni własną perspektywę praktyczną do przekazywanej przez nią treści, udzielić kadrze informacji zwrotnej na temat proponowanych programów nauczania z punktu widzenia nabytych doświadczeń na rynku pracy, czy też pomóc w prowadzeniu badań aplikacyjnych. Ponadto, z perspektywy psychologicznej, wejście 
w szerszą sieć społeczną pozwala na zdynamizowanie całej struktury, wzmocnienie innowacyjności jej wszystkich elementów składowych ${ }^{6}$. Korzystają więc na tym wszyscy. Warto zwrócić też uwagę, że przy tym podejściu stymulowane są również kontakty w ramach grupy absolwentów mimo skończenia studiów mogą stanowić oni zwartą grupę o własnej tożsamości, wspierając się, aktywnie uczestnicząc w życiu społecznym uczelni. Absolwenci powinni więc w znacznej mierze kształtować swoją macierzystą Alma Mater.

\section{Uczelnia w sieci społecznej}

\section{Zdaniem Nicholas A. Christakisa oraz Jamesa H. Flowera,}

społeczność sieciowa (network community) to grupa osób, które są ze sobą związane dużo ściślej niż z członkami innych grup powiązanych ze sobą ludzi, znajdujących się $\mathrm{w}$ pozostałych częściach sieci ${ }^{7}$.

Twierdzą oni, że sieć społeczna stanowi „nadorganizm”. Działa podobnie jak mrowisko, w którym owady wchodzą ze sobą w rozmaite interakcje, na ogół kooperując ze sobą niczym "globalny układ nerwowy". Najbliższa rodzina bezsprzecznie udziela nam dużego wsparcia $w$ trudnych sytuacjach $^{8}$, jednak okazuje się, że to właśnie znajomi, koledzy i koleżanki tworzący z nami słabe więzi mają często większe znaczenie dla uzyskania informacji czy rozmaitej pomocy (z pracą włącznie) ${ }^{9}$.

Uczelnia jest niewątpliwie ważnym elementem sieci społecznej. W społeczności akademickiej możemy wyróżnić trzy główne grupy: studentów, kadrę naukowo-dydaktyczną oraz absolwentów. Grupy te pozostają we wzajemnej relacji, która często nie wyczerpuje swojego potencjału, a w

${ }^{6}$ Zob. K.A. Bantel, S.E. Jackson, Top management and innovations in banking: Does the composition of the top team make a difference? Strategic Management Journal, 1989, 10, s. 107-124; $\mathrm{N}$. Bassett-Jones, The paradox of diversity management, creativity and innovation, Creativity and Innovation Management, 2005, 14, s. 169-175; M.F. Özbilgin, Global Diversity Management, [w:] The Handbook of Cross-Cultural Management Research, red. P. Smith, M.F. Peterson, D.C. Thomas, London 2008, s. 379-396.

7 N. Christakis, J.H. Fowler, W sieci. Jak sieci spoteczne kształtuja nasze życie, Sopot 2011, s. 22.

8 B. Wellman, S. Wortley, Different strokes from different folks, American Journal of Sociology, 1990, 3, s. 558-588.

${ }_{9}$ M. Granovetter, The Strength of Weak Ties, American Journal of Sociology, 1973, 78, s. $1360-1380$. 
przypadku absolwentów kontakt z edukacją zwykle kończy się bezpowrotnie po ukończeniu studiów.

W roku 2013 w ramach projektu „Model ksztatcenia przez całe życie w oparciu o trwała relacje z uczelnią: ideAGORA - absolwenci kapitałem uczelni" (o którym będzie jeszcze mowa szerzej w dalszej części) przeprowadzono ogólnopolskie badania zatytułowane „Diagnoza potrzeb uczelni, studentów $i$ absolwentów w zakresie budowania trwatych relacji uczelnia - student - absolwent opartych na wzajemnej wymianie wiedzy $i$ doświadczenia"10.

Określono następujące cele szczegółowe badania:

1) ocena stanu wzajemnej relacji absolwent - uczelnia;

2) ocena oczekiwań, potrzeb studentów i absolwentów w zakresie budowania wzajemnych relacji $\mathrm{z}$ uczelnią $\mathrm{w}$ dalszym procesie kształcenia i funkcjonowania na zmieniającym się rynku pracy oraz dostępu do zgromadzonej wiedzy na uczelni;

3) diagnoza gotowości uczelni i absolwentów do budowania trwałej relacji, której efektem będzie wzajemny transfer wiedzy $\mathrm{w}$ zakresie nauki i praktyki;

4) ocena możliwych perspektyw rozwoju uczelni oraz jej absolwentów w wyniku nowego podejścia do relacji absolwent - uczelnia.

Głównym modułem badawczym w ramach omawianego etapu diagnozy potrzeb było badanie ilościowe CAWI - sondaż elektroniczny z udziałem studentów i absolwentów szkół wyższych o zasięgu ogólnokrajowym $(\mathrm{N}=630 ; 12 \text { uczelni: } 6 \text { publicznych, } 7 \text { niepublicznych z } 6 \text { województw })^{11}$.

Wyniki badania kwestionariuszowego $\mathrm{z}$ udziałem studentów i absolwentów krajowych uczelni pokazały ogólnie, że głównym problemem dla rozwoju korzystnych dla obu stron relacji uczelnia-absolwent jest brak wypracowanego modelu współpracy w tym zakresie - kultura organizacyjna uczelni ma często tradycyjnie pionowy charakter, kształcenie studentów odbywa się z pominięciem rozbudzania potrzeby nauki przez całe życie, a rola absolwenta $\mathrm{w}$ życiu uczelni jest pomijana. Zdaniem studentów, biura karier i kluby absolwentów nie spełniają swojej funkcji integracyjnej i wspie-

10 Collegium Mazovia, Raport z realizacji badania pogtębionego „Diagnoza potrzeb uczelni, studentów i absolwentów w zakresie budowania trwatych relacji uczelnia - student - absolwent opartych na wzajemnej wymianie wiedzy $i$ doświadczenia" przeprowadzonego w ramach projektu innowacyjnego "Model ksztatcenia przez całe życie w oparciu o trwata relacje z uczelnia ideAGORA - absolwenci kapitatem uczelni", Siedlce 2013. http://www.ideagora.mazovia.edu.pl/sites/ideagora/ files/pages/673/zalacznik11_raport_z_ewaluacji_wstepnej_wersji_produktu_finalnego.pdf

$11 \mathrm{~W}$ ramach projektu przeprowadzono dodatkowo pogłębione wywiady grupowe (FGI) służące poznaniu opinii i poglądów wszystkich interesariuszy projektu (6 osób) oraz pogłębione wywiady indywidualne (IDI) z przedstawicielami kadry naukowo-dydaktycznej oraz ekspertami Life Long Learning (10 wywiadów). 
rającej $\mathrm{w}$ rozwoju, 3/4 studentów zupełnie nie korzysta $\mathrm{z}$ nich, a jako przyczyny tego stanu rzeczy wymienia się m.in. posiadaną ofertę, która nie odpowiada potrzebom i oczekiwaniom studentów $(27 \%)$ czy też nieefektywne działanie (23\%). Więź studentów z uczelnią słabnie już w trakcie studiowania. Powyżej trzeciego roku studiów aktywność w życiu studenckim i poczucie wspólnoty z nią drastycznie się obniża. Nie jest podtrzymywana motywacja i chęć działania tak wyraźnie widoczna u studentów I roku. Ale nie można bynajmniej z tego wysuwać wniosków, że młodzież przestaje być zupełnie aktywna. Wydaje się raczej, że ich działalność przenosi się na inne, pozauczelnianie obszary (np. staże, wolontariaty, praca, czy też rozmaite formy rozrywki). Świadczyć mogą o tym ogólnopolskie dane zgromadzone przez PARP12. Studenci często angażują się w rozmaite aktywności służące podnoszeniu kwalifikacji - 1/4 studentów oprócz studiowania uczestniczy dodatkowo w kursach, szkoleniach, lekcjach dodatkowych, stażach, czy praktykach.

Jak wynika z raportu Collegium Mazovia ${ }^{13}$, studenci narzekają na poziom zajęć, nieaktualną wiedzę, czują się na uczelni niekomfortowo w kontaktach z kadrą akademicką i administracją, zwracają też uwagę na konieczność wprowadzenia większej liczby zajęć praktycznych.

Wspomniane badania PARP14 to potwierdzają - 1/4 studentów deklaruje, że $\mathrm{w}$ trakcie studiów nie uczy się wykorzystywania zdobytej wiedzy w praktyce. Staże i praktyki, jakie odbywają w trakcie studiów, często są mocno poniżej posiadanych kompetencji albo są zupełnie niedopasowane, a tym samym nie zwiększają szans na znalezienie pracy w przyszłości. Sondaż ten ujawnił jednocześnie, że studenci mają bardzo wysoką świadomość konieczności uzupełnienia posiadanego wykształcenia. A jak to wygląda w ocenie absolwentów? Okazuje się, że dość podobnie - przyznają, że z uczelni wynieśli głównie wiedzę teoretyczną (64\%), a większość badanych przedsiębiorców - absolwentów twierdziła, że program kształcenia nie przygotował ich zupełnie do aktywności zawodowej (73\%). Mimo wszystko jednak, eks-studenci chcieliby utrzymać kontakt ze swoim miejscem studiowania $\mathrm{w}$ rozmaitej formie. Szczególnie przedsiębiorcy są bardzo zainteresowani $(82 \%)$ wzajemną wymianą wiedzy z danego obszaru zawodowego, nieco mniejszą potrzebę $w$ tym zakresie zgłaszają pracownicy, ale wciąż jest ona wysoka (59\%). Absolwenci wskazywali na współpracę w formie dzielenia się wiedzą ze studentami (35\%), doradztwa biznesowego (26\%), chatu ze

12 PARP, Studenci - przyszłe kadry polskiej gospodarki.

${ }^{13}$ Collegium Mazovia, Raport $z$ realizacji badania.

${ }^{14}$ PARP, Studenci - przyszłe kadry polskiej gospodarki. 
studentami/wykładowcami (20\%), czy recenzowania case study studentów (19\%). Byli studenci najchętniej chcieliby móc nadal korzystać z zasobów uczelni w formie dostępu online do biblioteki uczelni (34\%), brać udział w kursach zawodowych (25\%), mieć dostęp do najnowszych publikacji i badań prowadzonych przez uczelnię oraz uczestniczyć w forum dyskusyjnym z udziałem wykładowców (po 18\%). Przeprowadzone badanie pokazało coś jeszcze ważnego i być może trochę zaskakującego - aż $85 \%$ absolwentów odczuwa potrzebę dokształcania się, 59\% jest zainteresowanych otrzymywaniem informacji dotyczących swojej macierzystej uczelni (oferta, aktualności, dorobek naukowy, newsy itp.). Ich zdaniem może to być forma newslettera z życia uczelni (35\%) lub cykliczne spotkania absolwentów (25\%). Największym zainteresowaniem cieszą się studia podyplomowe $(40 \%)$, ale też krótsze formy szkoleniowe, jak: seminaria, kursy, czy warsztaty $(37 \%)$.

Mimo istniejącej motywacji do podtrzymywania związków ze swoją byłą uczelnią relacja ta jest wyraźnie zaniedbana. Badanie pokazało, że ponad połowa abiturientów nie miała pojęcia czy na terenie uczelni, którą skończyli działa jakiś klub absolwenta. Nie ma się co dziwić, że blisko $90 \%$ nie korzysta $\mathrm{z}$ oferty takich klubów. Jedynie $11 \%$ jest zaangażowanych $\mathrm{w}$ życie uczelni po odejściu z niej i utrzymuje z nią kontakt, natomiast $59 \%$ całkowicie zerwało $z$ nią więź. Co ciekawe, jeśli chodzi o przedsiębiorców - żaden $\mathrm{z}$ nich nie utrzymuje stałej więzi z uczelnią, a jedynie $17 \%$ robi to sporadycznie.

Wyniki zacytowanego badania prowadzą do konkluzji, że studenci domagają się kontaktów z praktyką, a praktycy głębszej relacji ze środowiskiem akademickim. Wydaje się, że potencjał absolwentów nie jest należycie wykorzystywany (zwłaszcza doświadczenia przedsiębiorców) i kontakt $\mathrm{z}$ wieloma $\mathrm{z}$ nich został bezpowrotnie utracony, ale zapewne inwestycja w postawy obecnych studentów utrwali więź po ukończeniu przez nich studiów.

Z punktu widzenia teorii sieci społecznych, kontakty pomiędzy absolwentami wydają się nawet ważniejsze niż między studentami. Uczestnictwo w słabych sieciach społecznych może dawać silne efekty w postaci znalezienia pomocy, wsparcia, pracy, czy nowych rynków zbytu. Niestety, takie struktury jak kluby absolwenta czy rozmaite stowarzyszenia absolwentów nie zaspokajają należycie potrzeb społecznych - spotkania absolwentów, szkolenia czy uroczystości uczelnianie pozwalają jedynie na sporadyczne kontakty. Prawdziwa siatka połączeń następuje wówczas, kiedy szerokie interakcje nawiązywane są pomiędzy poszczególnymi jednostkami w sieci. 


\section{Innowacyjny model kształcenia ideAGORA}

Analiza obecnej relacji: uczelnie - absolwenci stała się podstawą projektu zatytułowanego "Model kształcenia przez całe życie w oparciu o trwata relacje $z$ uczelnia: ideAGORA - absolwenci kapitatem uczelni", prowadzonego przez Collegium Mazovia Innowacyjną Szkołę Wyższą. Jest on odpowiedzią na konkurs ogłoszony przez Narodowe Centrum Badań i Rozwoju w grudniu 2011 roku$^{15}$.

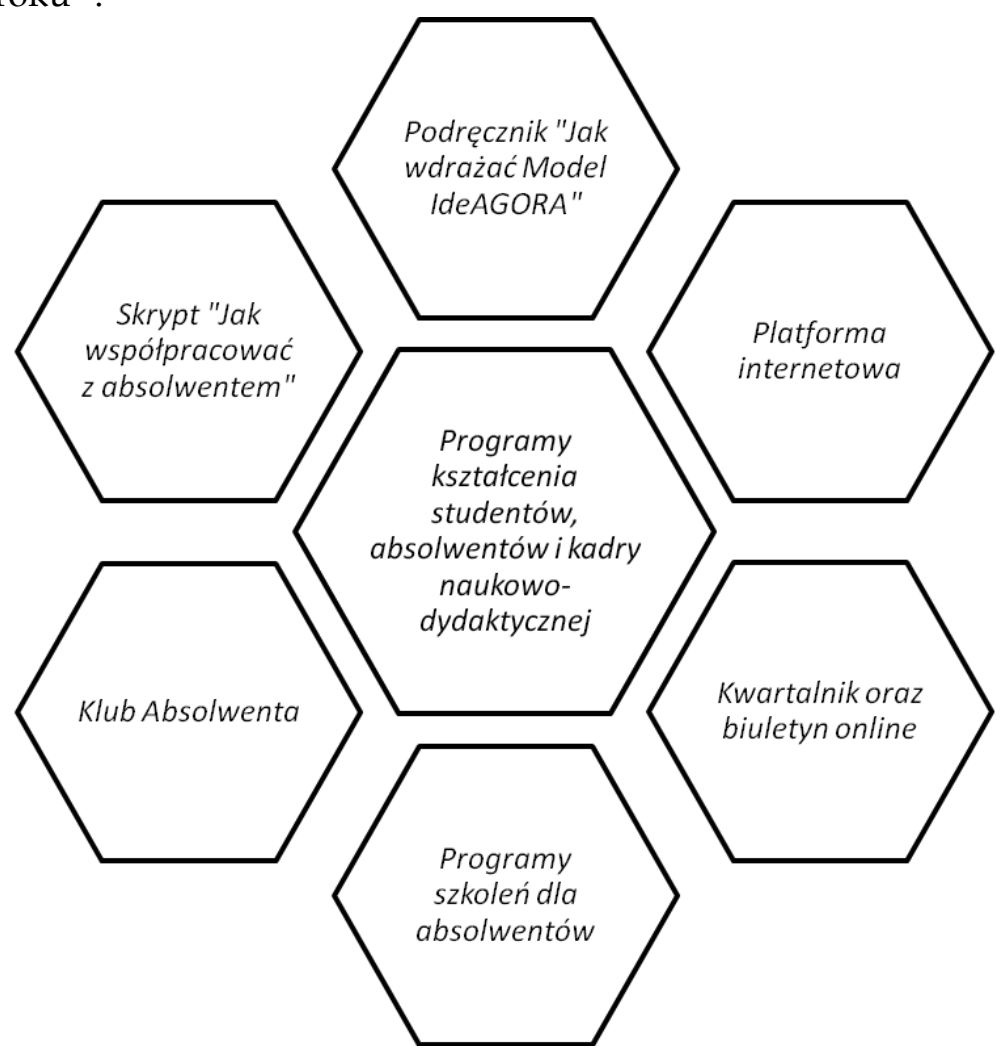

Rys. 3. Elementy modelu ideAGORA (opracowanie własne)

${ }^{15}$ Projekt współfinansowany przez Unię Europejską w ramach Europejskiego Funduszu Społecznego Priorytet IV. Szkolnictwo Wyższe i Nauka, Działanie 4.1 Wzmocnienie i rozwój potencjału dydaktycznego uczelni oraz zwiększenie liczby absolwentów kierunków o kluczowym znaczeniu dla gospodarki opartej na wiedzy, Poddziałanie 4.1.1 Wzmocnienie potencjału dydaktycznego uczelni Programu Operacyjnego Kapitał Ludzki. Czas trwania: 01.11.2012 30.10.2015. Projekt otrzymał drugie miejsce (na 20 wyróżnionych) w konkursie, do którego przystąpiły 162 uczelnie. 
Głównym celem projektu było zbudowanie, poprzez wypracowanie innowacyjnego modelu kształcenia przez całe życie opartego na trwałej relacji absolwenta z uczelnią, aktywnej społeczności absolwentów, działającej na rzecz uczelni, wykształcenie liderów zmian, których zadaniem będzie kształtowanie postaw i umiejętności przyszłych absolwentów potrafiących osiągać własne korzyści poprzez dzielenie się z innymi członkami społeczności. Model ideAGORA propaguje więc model kształcenia ustawicznego, dopasowanego nie tylko do zindywidualizowanych potrzeb swoich absolwentów, ale również do dynamicznie zmieniającej się rzeczywistości społecznej i zawodowej, w której będą oni później funkcjonować.

Model ten ma charakter systemowy oraz kompleksowy i składa się z kilku elementów. Choć opis każdego z nich mógłby stanowić osobny artykul, poniżej zostaną one przedstawione na schemacie graficznym i skrótowo scharakteryzowane ${ }^{16}$.

Podręcznik "Jak wdrażać model ideAGORA" - celem opracowania było wyjaśnienie istoty modelu ideAGORA oraz ułatwienie zainteresowanym uczelniom wdrażanie go w życie.

Skrypt "Jak wspótpracować z absolwentem" - dokument przedstawia zalecenia związane ze współpracą $\mathrm{z}$ absolwentami, w tym różne przykłady zagraniczne (Finlandia, USA).

Platforma internetowa ideAGORA - innowacyjny, specjalnie zaprojektowany serwis internetowy, który służy zgromadzonej wokół uczelni społeczności. To wirtualny obszar łączący studentów, absolwentów oraz kadrę uczelni w czasie wolnym od zajęć. Integruje w jednym miejscu najbardziej potrzebne funkcjonalności i informacje.

Kwartalnik ideAGORA oraz biuletyn online - ukazuje się zarówno w formie tradycyjnej, jak i elektronicznej. Znajdują się w nim ciekawostki i wydarzenia z życia uczelni, informacje na temat projektu ideAGORA i działań wokół niego, kształcenia ustawicznego, rynku pracy oraz życia społecznego i gospodarczego. Uzupełnieniem dla pisma jest biuletyn online publikowany raz w miesiącu na stronie internetowej kwartalnika.

Programy kształcenia studentów, absolwentów i kadry naukowo-dydaktycznej miały na celu wyrobienie potrzeby ciągłego doskonalenia się oraz wzajemnej współpracy (studentów, absolwentów, kadry) opartej na długoterminowym związku absolwentów z uczelnią. Duże znaczenie przy konstruowaniu i realizacji programów miał fiński model kształcenia, gdzie biznes i pracodawcy aktywnie uczestniczą w kształceniu studentów i absolwentów.

${ }^{16}$ Pełna dokumentacja na stronie: http://www.ideagora.mazovia.edu.pl/opracowania 
Programy szkoleń dla absolwentów - cykl unikatowych szkoleń dla absolwentów w ramach kształcenia ustawicznego. Szkolenia, skonstruowane $\mathrm{w}$ oparciu o system kompetencji, miały na celu pomoc absolwentom w dobrym przygotowaniu do rozpoczęcia kariery zawodowej i utrzymaniu stabilnej pozycji na rynku pracy.

Klub Absolwenta - stanowi połączenie centrum informacyjnego i rozwojowego dla absolwentów, w którym organizowane są warsztaty samokształceniowe, kursy specjalistyczne, ale także spotkania integracyjno-networkingowe służące budowaniu trwałych relacji pomiędzy absolwentami a otoczeniem uczelni.

„Produkty finalne” projektu zostały wdrożone i poddane testowaniu w ramach realizowanego projektu w Collegium Mazovia od marca do października 2014 roku. Proces polegał na:

1. Wdrożeniu programów kształcenia studentów, absolwentów oraz kadry naukowo-dydaktycznej.

2. Monitoringu aktywności studentów i absolwentów na Platformie ideAGORA Uczelni.

3. Organizacji i przeprowadzeniu przez absolwentów spotkań samokształceniowych.

4. Pozyskiwaniu od absolwentów wiedzy o rynku pracy.

5. Monitoringu otwartych zasobów uczelni - biblioteka zasobów uczelni (monitoring poziomu zainteresowania, liczba pobranych poprzez platformę materiałów).

Po okresie testowania modelu ideAGORA przeprowadzono badania ewaluacyjne od września do grudnia 2014 roku17. Celem głównym było zebranie opinii na temat wstępnej wersji produktu finalnego Modelu ideAGORA oraz korzyści (efektów), jakie może przynieść jego zastosowanie.

Proces badawczy obejmował kilka grup:

- kadrę naukowo-dydaktyczną Collegium Mazovia, uczestniczącą w testowaniu programu kształcenia dedykowanego kadrze naukowodydaktycznej;

- studentów uczestniczącym $\mathrm{w}$ testowaniu programu kształcenia dla studentów;

17 Raport ewaluacyjny IdeAGORA. Ewaluacja wstępnej wersji produktu finalnego: „Model ideAGORA - absolwenci kapitałem społecznym Uczelni", Siedlce 2014.

http://www.ideagora.mazovia.edu.pl/sites/ideagora/files/pages/673/zalacznik11_raport_z _ewaluacji_wstepnej_wersji_produktu_finalnego.pdf 
- studentów ostatniego roku studiów (obecnie absolwentów) testujących program kształcenia dla absolwentów;

- absolwentów testujących program cyklu unikatowych szkoleń dla absolwentów w ramach kształcenia ustawicznego;

- kadrę naukowo-dydaktyczną, studentów i absolwentów - uczestników działań realizowanych w ramach współpracy ponadnarodowej.

W celu uzyskania pełnego obrazu sytuacji zebrano dane zarówno pierwotne, jak i wtórne. Dane pierwotne uzyskano dzięki anonimowemu badaniu ankietowemu (CAWI) oraz wywiadów indywidualnych (IDI) i grupowych (FGI).

Dane wtórne pozyskano na etapie monitoringu projektu - tzn. wyniki ankiet ewaluacyjnych szkoleń testujących, analizę aktywności na platformie ideAGORA oraz weryfikację działalności i oddziaływań takich elementów systemu, jak: Klub Absolwenta, Kwartalnik ideAGORA, Biuletyn miesięczny (gazetka internetowa) ${ }^{18}$.

Jakie dane przyniósł raport z wyników badań ewaluacyjnych ${ }^{19}$ ? Główne wnioski z badania CAWI $(\mathrm{N}=180)$ są takie, że absolwenci biorący udział $\mathrm{w}$ projekcie bardzo dobrze oceniali swoją relację $\mathrm{z}$ macierzystą uczelnią (81\%). $88 \%$ respondentów uznało, że oferta i działania uczelni zachęcają do utrzymywania z nią kontaktów po zakończeniu studiów, $72 \%$ badanych absolwentów otrzymuje stale informacje o ofercie uczelni. $63 \%$ respondentów zadeklarowało zamiar utrzymywania kontaktu z uczelnią lub aktywnego uczestniczenia w jej działalności. $64 \%$ respondentów widzi możliwość budowania relacji z uczelnią poprzez działalność na platformie ideAGORA lub uczestnictwo w działaniach organizowanych przez Klub Absolwenta. Aż 90\% respondentów oceniło model ideAGORA jako „bardzo użyteczny” oraz „użyteczny”. W opinii $78 \%$ respondentów wdrożenie modelu przyczyni się do bardziej skutecznego wsparcia absolwentów na rynku pracy. $78 \%$ respondentów uznało również, że wdrożenie modelu ideAGORA przyniesie w przyszłości zauważalną zmianę w relacji absolwent - uczelnia.

Dane zbierano również w grupie porównawczej nie biorącej udziału $\mathrm{w}$ projekcie ideAGORA. Kiedy obydwie grupy zapytano o własne plany $\mathrm{w}$ dziedzinie utrzymania kontaktu z uczelnią lub aktywnego uczestnictwa w jej działalności po zakończeniu kształcenia, okazało się, że takie plany mają głównie absolwenci uczestniczący w testowaniu modelu (50\%); tylko $10 \%$ z nich zdecydowanie nie zamierza utrzymywać kontaktu z uczelnią.

18 Pełen raport, wraz ze szczegółowym opisem metodologii, dostępny na stronie: http:// www.ideagora.mazovia.edu.pl/opracowania

${ }^{19}$ Raport ewaluacyjny IdeAGORA. 
W drugiej grupie respondentów tylko 22\% zamierza utrzymywać kontakt z uczelnią i aż 39\% jest przeciwnego zdania. Działania podejmowane przez uczelnię, jej oferta zachęcająca do utrzymania kontaktu zostały zdecydowanie najwyżej ocenione przez absolwentów biorących udział $\mathrm{w}$ testowaniu (90\%). Jedynie $22 \%$ absolwentów nie biorących udziału w projekcie oceniło ją pozytywnie, przy czym negatywne oceny wyraziło aż 33\% badanych. Preferowane przez absolwentów biorących udział $w$ testowaniu formy utrzymania kontaktu z uczelnią to głównie platforma ideAGORA (33\%) i kontakt mailowy/telefoniczny (33\%). Absolwenci biorący udział w testowaniu wykazują zdecydowaną wolę dzielenia się z uczelnią swoją wiedzą o rynku pracy - $80 \%$ pytanych. Absolwenci z grupy porównawczej w $89 \%$ odpowiadają na to pytanie negatywnie.

Indywidualne wywiady pogłębione (IDI) przeprowadzono z przedstawicielami kadry naukowo-dydaktycznej, które brały udział we wdrażaniu modelu ideAGORA. Opinie na temat projektu były niezwykle pozytywne. Respondentki, które wzięły udział w warsztatach testujących model, zwracały uwagę, że filozofia i metody kształcenia charakterystyczne dla modelu ideAGORA przede wszystkim odpowiadają na potrzeby studentów i wymagania rynku pracy. Zdaniem większości z nich rozwiązanie to prowadzi do "zmiany całej uczelni", "zmiany podejścia do ksztatcenia na całej uczelni". Wdrożone rozwiązania mają szczególne znaczenie dla kształcenia umiejętności/kompetencji miękkich, obok zgłębiania wiedzy z konkretnej dziedziny - rozwijają one "bezcenna umiejętność pracy w zespole" i umiejętność zaufania innym, w tym uczelni. Model wpływa znacząco na kształcenie postawy gotowości do uczenia się przez całe życie - otwartości na nowe doświadczenia edukacyjne - u studentów (przyszłych absolwentów), jak i wśród nauczycieli. Uczy on „oduczania się", a następnie uczenia wiedzy/umiejętności z danego obszaru na nowo. Jak wyraził się jeden z pracowników: "My musimy uczyć studentów - $i$ siebie również - że trzeba o pewnych rzeczach zapomnieć $i$ nauczyć się czegoś zupetnie nowego".

Fakt, że nauczyciele też się uczą prowadzi do „integracji całego środowi$s k a^{\prime \prime}$, zwiększenia motywacji studentów oraz spostrzegania społeczności akademickiej jako wspólnoty. W związku z korzyściami respondentki rekomendują wdrożenie modelu na innych uczelniach (,Jak najbardziej na wszystkich uczelniach powinno to być wdrożone").

W ramach ewaluacji przeprowadzono również dwa badania typu focus group (FGI). W pierwszym wzięło udział 7 osób (2 wykładowców CM, 1 studentka, 2 absolwentów oraz 2 członków zespołu projektowego), w dru- 
gim spotkaniu wzięło udział 6 studentów różnych kierunków Collegium Mazovia.

Pierwsza grupa dużo uwagi poświęciła na obawy związane $\mathrm{z}$ wdrażaniem modelu ideAGORA wynikające z polskiej mentalności, której przeciwstawiali mentalność fińską (w ramach projektu odbyła się wizyta studyjna do jednej z fińskich uczelni).

W Finlandii zauważono więcej zaufania, partnerstwa, dzielenia się wiedzą, mocnego osadzenia w poczuciu własnej wartości, a także półoficjalność oraz wiele przestrzeni otwartych.

W przypadku grupy studentów można powiedzieć, że widzą oni w modelu ideAGORA zmianę relacji student - uczelnia. Oznacza on przejście z podejścia hierarchicznego, zamkniętego do bardziej partnerskiego i otwartego. Metody pracy ze studentami zostały więc przez respondentów uznane za innowacyjne i w dużej mierze odpowiadające na ich potrzeby. Wpływają one na automotywację, pojawia się "chęć, [żeby] móc wykorzystać to, co uczelnia daje, te szkolenia wszystkie". Respondenci dużo mówili o kształtowaniu się nowych pozytywnych relacji - tworzeniem nowych powiązań w różnych konfiguracjach (student - wykładowca, student - student, student - uczelnia, absolwent - uczelnia) i nowej formuły relacji (partnerskiej, otwartej, dwustronnej, zaangażowanej). Studenci wskazują na atrakcyjność formy prowadzonych zajęć "Wiedza jest bardziej przyswajalna, gdy możesz porozmawiać - na zasadzie dyskusji - o tym czego się uczysz". Postulują jednocześnie, że chcieliby mieć więcej zajęć $\mathrm{z}$ dydaktykami pracującymi zgodnie z koncepcją ideAGORA.

Dane wtórne zebrano poprzez analizę produktów materialnych, takich jak: (1) Platforma ideAgora, (2) Klub Absolwenta, (3) Kwartalnik i biuletyn ideAGORA.

Wbrew obawom aktywność na platformie ideAGORA była nadspodziewanie wysoka, co pokazują konkretne wskaźniki ilościowe: 2076 zarejestrowanych użytkowników, 698 wątków/tematów, które zostały skomentowane 10196 razy, 141 ofert pracy, 3298 przyznanych tzw. „lubików”20. Społeczność platformy stała się samoorganizującą się grupą, stanowiącą miejscami swoistą grupę wsparcia, gdyż wielokrotnie oferowano tam sobie wzajemnie pomoc, np. poprzez dystrybucję ofert pracy, źródeł wiedzy i doświadczenia.

Kwartalnik ideAGORA i biuletyn również dynamicznie się rozwinął. Do grudnia 2014 roku wydano 8 numerów kwartalnika (łączny nakład wyniósł 16 tys. egz.). W kwartalniku zamieszczono 83 artykuły, w tym: 21 tekstów

${ }^{20}$ Odpowiednik „polubień” na portalu Facebook. 
napisanych przez kadrę naukowo-dydaktyczną Collegium Mazovia, 3 teksty przygotowane przez kadrę naukowo-dydaktyczną innych uczelni, 19 tekstów opracowanych przez absolwentów, 14 tekstów studentów. Biuletyn jest medium dostępnym $\mathrm{w}$ wersji internetowej. Pozwoliło to na nieograniczony dostęp do jego zasobów w dowolnym miejscu i czasie. Do grudnia 2014 roku przygotowano 19 biuletynów ideAGORA.

Analiza działalności Klubu Absolwenta pokazała, że organizowano tam szereg warsztatów samokształceniowych, kursów specjalistycznych oraz spotkania networkingowe. Miejsce to wyposażono w system nagłośnienia audio, video, ekran, stół konferencyjny, wi-fi) tak, aby zachęcać do podejmowania samodzielnych inicjatyw, stwarzać warunki do spotkań i dyskusji zarówno bezpośrednich, jak też $\mathrm{w}$ formie telekonferencji. Dodatkowo, poprzez platformę ideAGORA, z inicjatywy absolwentów zawiązał się projekt „Tworzymy Klub Absolwenta”, w którym postanowili oni stworzyć miejsce według swojej wizji i na własne potrzeby, otrzymali więc od uczelni wybrane przez siebie pomieszczenie do wyłącznej dyspozycji, samodzielnie dokonali jego modernizacji.

Uogólniając zebrane dane można powiedzieć, że model ideAGORA ma udział w ewolucji formuły uczelni z instytucji wyłącznie edukacyjnej w społeczność skupioną wokół dzielenia się wiedzą (praktyczną, biznesową). Wpłynął on na głębsze zrozumienie idei „uczenia się przez całe życie”, podniósł się ich poziom aktywności i motywacji do udziału w różnych formach kształcenia ustawicznego. I co najważniejsze - model prowadzi do tworzenia więzi z uczelnią i poczucia wspólnoty wśród wszystkich zaangażowanych grup: kadry naukowo-dydaktycznej, studentów i absolwentów.

\section{Zakończenie}

Należy pamiętać, że jest to jedynie przykład projektu, w którym realizuje się idea stymulowania kształcenia przez całe życie, gdzie studenci, kadra i absolwenci stanowią sieć społeczną mocno osadzoną w otoczeniu społecznym. To propozycja dla „odważnych” uczelni, które chcą być konkurencyjne i odpowiadać na wyzwania współczesności. Jak przy okazji każdej zmiany, główną przeszkodą we wdrażaniu innowacji może być tzw. czynnik ludzki. Dlatego, ważnym obszarem zmiany są działania komunikacyjne przedstawiające indywidualne i zbiorowe korzyści wynikające z wdrożenia nowatorskich rozwiązań. 
Trzeba także dodać, że już podczas studiów warto przygotowywać studentów do roli absolwenta i uświadamiać im wagę kształcenia ustawicznego oraz utrzymania kontaktu z uczelnią. Starsi studenci (a lada moment absolwenci) tworzą coraz więcej powiązań społecznych ze światem pozauczelnianym, zdobywają pierwszą pracę, uczestniczą $\mathrm{w}$ rozmaitych stażach i praktykach. Po rozpoczęciu życia zawodowego każdy tworzy swoją wysepkę z własnymi połączeniami społecznymi. Model ideAGORA traktuje jednak te wyspy nie jako coś osobnego, ale jako jeden wielki archipelag, gdzie centralne miejsce zajmuje uczelnia, a pomiędzy wysepkami utrzymywana jest stała łączność.

\section{BIBLIOGRAFIA}

Bantel K.A., Jackson S.E., Top management and innovations in banking: Does the composition of the top team make a difference? Strategic Management Journal, 1989, 10.

Bassett-Jones N., The paradox of diversity management, creativity and innovation, Creativity and Innovation Management, 2005, 14.

Christakis N.A., Fowler J.H., W sieci. Jak sieci społeczne kształtują nasze życie, Smak Słowa, Sopot 2011.

Collegium Mazovia, Raport z realizacji badania pogłębionego „Diagnoza potrzeb uczelni, studentów $i$ absolwentów $w$ zakresie budowania trwatych relacji uczelnia - student - absolwent opartych na wzajemnej wymianie wiedzy $i$ doświadczenia" przeprowadzonego w ramach projektu innowacyjnego "Model ksztatcenia przez całe życie w oparciu o trwała relacje z uczelnia ideAGORA - absolwenci kapitatem uczelni", POKL, Siedlce 2013. http://www. ideagora.mazovia.edu.pl/sites/ideagora/files/pages/673/zalacznik11_raport_ z_ewaluacji_wstepnej_wersji_produktu_finalnego.pdf

Deklaracja Bolońska, Szkolnictwo wyższe w Europie. Wspólna Deklaracja Europejskich Ministrów Edukacji, zebranych w Bolonii w dniu 19 czerwca 1999. http://ekspert cibolonscy.org.pl/sites/ekspercibolonscy.org.pl/files/1999_PL_

Bologna_Declaration.pdf

Ernst\&Young, IBNGR. Strategia rozwoju szkolnictwa wyższego w Polsce do 2020 roku, 2009. https://www.nauka.gov.pl/g2/oryginal/2013_05/59579f9e6efaec82014d6d5be081ca 23.pdf

Granovetter M., The Strength of Weak Ties, American Journal of Sociology, 1973, 78, s. $1360-80$.

Matwijów B., Kształcenie akademickie w perspektywie uczenia się przez całe życie (lifelong learning), [w:] W poszukiwaniu modelu dydaktyki akademickiej, red. D. Skulicz, Wydawnictwo Uniwersytetu Jagiellońskiego, Kraków 2004.

Ministerstwo Nauki i Szkolnictwa Wyższego, Reforma Szkolnictwa Wyższego, 2011. http://www.nauka.gov.pl/g2/oryginal/2013_05/c206c1142bb1abce72e45bb9a3a392 9e.pdf

Özbilgin M.F., Global Diversity Management, [w:] The Handbook of Cross-Cultural Management Research, red. P. Smith, M.F. Peterson, D.C. Thomas, London 2008. 
PARP, Studenci - przyszłe kadry polskiej gospodarki. Raport z badań studentów i analizy kierunków ksztatcenia realizowanych w 2010 r. w ramach projektu "Bilans Kapitału Ludzkiego" (oprac. M. Jelonek), 2011. http://bkl.parp.gov.pl/system/files/Downloads/20110 616070806/Studenci_-_przyszle_kadry_polskiej_gospodarki.pdf?1309349876.

Raport ewaluacyjny IdeAGORA. Ewaluacja wstępnej wersji produktu finalnego: Model ideAGORA - "Absolwenci kapitałem społecznym Uczelni”, Siedlce 2014. http://www.ideagora.mazovia.edu.pl/sites/ideagora/files/pages/673/zalacznik11 _raport_z_ewaluacji_wstepnej_wersji_produktu_finalnego.pdf

Wellman B., Wortley S., Different strokes from different folks, American Journal of Sociology, $1990,3$. 